\title{
Unfolding authenticity within retail gentrification in Mouraria, Lisbon
}

\section{Pedro Porfírio Coutinho Guimarães}

To cite this article: Pedro Porfírio Coutinho Guimarães (2021): Unfolding authenticity within retail gentrification in Mouraria, Lisbon, Journal of Tourism and Cultural Change, DOI: 10.1080/14766825.2021.1876079

To link to this article: https://doi.org/10.1080/14766825.2021.1876079

$$
\text { 曲 Published online: } 02 \text { Feb } 2021 .
$$

Submit your article to this journal $匚$

\section{Џ Article views: 66}

Q View related articles $\longleftarrow$

View Crossmark data ¿ 


\title{
Unfolding authenticity within retail gentrification in Mouraria, Lisbon
}

\author{
Pedro Porfírio Coutinho Guimarães \\ Centre for Geographical Studies, Institute of Geography and Spatial Planning, Universidade de Lisboa, \\ Lisbon, Portugal
}

\begin{abstract}
Retail gentrification is gaining relevance to study the transformation of several urban districts. In this article we explore the connections between this process and the appropriation and use of the elements of authenticity of a given urban district. Drawing upon the production standpoint, we based our research on the objective, constructivist and existential perspective of the concept of authenticity. We developed fieldwork on Mouraria, a traditional neighbourhood of Lisbon city centre, affected by gentrification as a consequence of a strong growth of tourism in the last decade. Information was collected about the size and evolution of the commercial fabric and business owners were interviewed. Its treatment allows to gather three set of elements that were considered as representative of the authenticity of Mouraria: community values, multiculturality and urban features. The way retail spaces use these elements is diverse and intertwined with the different perspectives of authenticity and, on the part of business owners, arises as a management practice. Although Mouraria can be currently placed within an early stage of retail gentrification, the current pace of retail change and gentrification occurring in the neighbourhood may led to a wider replacement of the commercial fabric with detrimental consequences for local residents.
\end{abstract}

\section{ARTICLE HISTORY}

Received 17 July 2020

Accepted 8 January 2021

\section{KEYWORDS}

Retail gentrification; gentrification; authenticity; Lisbon; Mouraria; touristification

\section{Introduction}

Geographies of retailing is a wide scientific field (Crewe, 2000) and the relation between retail activities and the spaces where they take place is deeply rooted in the studies on retail geography (Guimarães, 2019). Although early studies were focused on the hierarchies of centres of commerce based on locational theories (Mayhew, 2015), Wrigley and Lowe (1996) claims that in the mid-nineteen's a new retail geography emerged. Within this, Wrigley and Lowe (2002) established some key issues which, roughly speaking, encompasses most of the studies on retail geography: (i) reconfiguration of corporate structures in retailing; (ii) retailer-supply chain interfaces; (iii) organisational and technological transformations in retail distribution; (iv) changing retail employment relations; (v) retail regulation; (vi) spatial interference of retail capital; (vii) and consumption places and spaces. More recently, online retail is introducing new challenges to the retail industry, 
gaining market share from traditional brick-and-mortar stores (Fan, Tang, Zhu, \& Zou, 2018), and leading to an increase of studies devoted to the subject. Some concerns were raised, arguing that this evolution would lead to a deterritorialization of retail. However, the relation between retail and urban spaces still remains very strong, as it is in these areas that retail better express itself (Guimarães, 2016). As referred by Johnston, Gregory, Pratt, and Watts (2000, p. 714), 'retail capital can structure space in particular ways, yet, is itself configured by socio-spatial processes, such as nation-specific "corporate cultures"'. In the UK, policy documents, such as Portas report (Portas, 2011), Grimsey Review (Grimsey, 2018) and Fraser Review (Scottish Government, 2013) claim for the relevance of such relation. In the last years, retail gentrification has been used by some academics to enlighten about the evolution of the commercial fabric in certain urban districts, characterised by the direct and indirect displacement of traditional stores, that are replaced by new retail places that aim for new and wealthier clientele.

In this article we explore the reciprocity between urban spaces and retail activities by uncovering how the authenticity of a given neighbourhood is used in retail spaces within a context of retail gentrification. Our approach to authenticity will be done through the consideration of the objective, constructivist and existential perspectives. For this purpose, among other authors, we will draw upon the work of Cohen (2007) and Wang (1999). Other authors could have been used as well as their diverse understandings of that concept (see for instance Bruner, 1994; Zukin, 2008, 2009). However, this is not the purpose of this paper, as we intend not to analyse 'authenticity' per si but the how concept is used by retail business owners in their management practices and the relation it has with processes of urban transformation, particularly with retail gentrification that currently affects Lisbon city centre.

Our research is spatially circumscribed to Mouraria, an historical old neighbourhood of Lisbon that has been deeply affected by gentrification that affects Lisbon (see Barata-Salgueiro, Mendes, \& Guimarães, 2017). We aim to apprehend how authenticity is explored in retail stores, further discussing if this procedure is promoting and intensifying the process of commercial transformation of the area. We have anchored the research in the following research questions: (i) Which elements are considered as most representative, distinguishing and authentic of Mouraria? (ii) Are retail stores of Mouraria using these elements, and if so, how? (iii) Are there any territorially visible impacts that arise from this process? We argue that the authenticity ofMouraria is being appropriated and used in the stores of the neighbourhood in different ways, increasing the depth of changes in the commercial fabric of the neighbourhood, which can be framed within processes of retail gentrification.

\section{Theoretical framework}

Cities have long been the space for class struggles and recent developments, namely after the last economic crisis, were unable to tackle socio-economic inequalities (Harvey, 2012). As a matter of fact, overall, public policies have focused on the establishment of neoliberal policies that seem to exacerbate these same inequalities (González-Pérez, 2018). The concept of gentrification, coined half a century ago by Ruth Glass (Lees, Slater, \& Wyly, 2008), has been evolving (Aalbers, 2019) and is gaining significance in the study of this uneven development that increasingly seems to affect a larger portion of the population. It should be seen as a globalised problem (Lees, 2018), in the sense it is connected with 
broader economic and social processes, such as banking deregulation and state restructuring (Hackworth, 2019). Displacement is also an important aspect to be considered in gentrification studies (Hubbard \& Lees, 2018; Lees et al., 2008) because it is one of the negative effects of gentrification that entails strong social costs for affected populations.

It is on the dichotomy basis that stems from the transformation of a declining neighbourhood into a regenerated trendy neighbourhood that we find the mantle that covers the negative effects of gentrification. As discussed by Slater (2006), the negative effects of gentrification are usually seen as a better option than the previous declining state of regenerated neighbourhoods. In a critical attitude to this understanding, this author claims for the need of a critical approach within gentrification studies - 'The eviction of critical perspectives is very serious for those whose lives are affected by reinvestment designed for the middle-class colonization of urban neighbourhoods' (Slater, 2006, p. 752). He further deeps his thought through Wacquant (2004, p. 101) understanding that 'critical thought must, with zeal and rigour, take apart the false commonplaces, reveal the subterfuges, unmask the lies, and point out the logical and practical contradictions of the discourse of King Market and triumphant capitalism'.

\section{Retail gentrification}

With an initial focus on the study of the transformations in the housing sector (Bounds \& Morris, 2006), in time, Smith (2002) identified a third wave of gentrification that began in the 1990s and in which the author assumes to exist a world-wide generalisation of gentrification. In addition to the globalisation of the phenomenon, the same author (Smith, 2006) considers that, in this new wave, gentrification studies are also characterised by being sectorially more comprehensive, including transformations in the commercial fabric and tourism. Retail gentrification is one example of such evolution but still remains an underexplored subject of research (Hubbard, 2018) within gentrification studies. Traditionally, the change in the commercial fabric is usually perceived as a consequence of a previous transformation of the social composition of a given neighbourhood. For instance, in Lees et al. book (2008, p. 131) the authors refer to the gentrification of Upper Street and Seventh Avenue 'not long after pioneer gentrifiers moved into those neighbourhoods'. In general, we may look at retail gentrification as the 'displacement of traditional shops, grocery stores, cafes and other local and independent stores by new luxury stores, exclusive restaurants and clubs' (Guimarães, 2018a, p. 1454). Because the new commercial fabric caters for a new and wealthier clientele, this transformation poses serious problems to urban retail systems in their capacity to supply the most vulnerable local populations. As in broader gentrification studies focused on other sectors, as one witnesses the profound transformations of the commercial fabric in a certain deprived site, it is easy to let ourselves deceived by the ongoing change that bring to the area new trendy businesses such as art galleries, boutiques, cafes and restaurants as Zukin identified in her study of Harlem and Brooklyn in New York (Zukin, 2009), which reflect an aura of a healthier economy and of success for the area (Slater, 2006). Still, this perception is a misconception if one considers the growing socio-economic inequalities brought by the change. 


\section{Finding authenticity within retail}

For almost half a century that authenticity is being used in numerous studies (Cohen, 2007). Although its use in tourism studies has gain some prominence, it is not limited to this research field (Castéran \& Roederer, 2013). Nevertheless, one must still recognise that there isn't a single understanding of the concept of authenticity. For the current research we use the widespread three approaches to authenticity in tourism studies: objective, constructive and existential authenticity (Wang, 1999). In the former approach, objects, places and cultural-linked features possess an authenticity by itself, inherent to the respective feature. Nevertheless, as pointed and discussed by Sims (2009), societies evolve over time, thus, the notion that some aspects of today's culture are 'pure' and unaltered has no grounds. The constructivist approach takes in consideration that to view authenticity as the original or the attribute of the original is too simple to capture its complexity' (Wang, 1999, p. 353). In this approach, reality should be seen as socially constructed, thus, subjective, evolutionary and capable to be apprehended differently by individuals. Lastly, existential authenticity. In tourism studies, this approach is linked with the tourist development of 'an authentic sense of self' (Sims, 2009, p. 325). This understanding lays on the consideration that the tourist search for authenticity and the construction of this authenticity by the diverse range of businesses working in the tourism industry does not explain all of the process. Existential authenticity is, therefore, concerned with the 'need to escape or keep distance from one's daily routine' (Fu, 2019, p. 84). Wang (1999, p. 359) exemplifies how rumba, if treated 'as a toured object' fits within objective authenticity but once it is 'turned in a tourist activity' falls within existential authenticity. In the same way, the adaptation of some heritage locations (Martínez, 2016) is made to allow tourists to obtain some meaning from their travel experiences (Fu, 2019).

The incorporation of authenticity in retail is not new but has been gaining relevance. The highly dynamics of the sector (Cachinho \& Barata-Salgueiro, 2016; Guimarães, 2018b) has led to the appearance and gain of importance of new retail formats, commercial practices and centralities. Simultaneously, traditional retail formats, such as small groceries, have been disappearing; former personal connections between retailers and clients have been substituted by cash and carry practices and some traditional centres of commerce declined in detriment of other areas. This substitution of the old for the new, that is no more than the reflex of the evolutionary nature of retail is usually accompanied by the feeling that the new is not authentic, as it lacks its genuineness, a sense that Cohen (2007) assumes to be one of the ways in which objective authenticity is apprehended.

The production of authenticity in retail intend to embed the traded products or experiences with a feeling of authenticity, aiming for consumers, tourists and other visitors, that are trying to alienate themselves from their daily routine (Brown, 2013). For instance, Thomsen (2018) demonstrates how retailers in Vietnam built a false idea of perceived authenticity around the production of clothing just to cater costumers that search genuineness in the products they bought. In another example, Shaker and Rath study (2018) demonstrate how coffee bars supply the needs of authenticity of a part of the population that search alternatives for Starbucks-related mass-consumption stores. In this particular example, the authenticity of coffee shops is an element of differentiation from now-a-days mass-market stores (Gelmers, 2015) but is, simultaneously, linked with traditional retail 
practices and stores; in this case, coffee is sold for its objective authenticity but its appropriation byconsumers fits within existential authenticity. Moreover, several elements of authenticity are connected with specific places (Thomsen, 2018), in spatially defined areas, whether we may be discussing products or elements representatives of a certain culture (see Zhu, 2015). Therefore, these authenticity elements possess a given spatial capital, although not exactly in the form of position capital or situation capital as defined by Lévy (1994), which means that there is an intangible asset possessed by some areas by means of the historic elements that are transformed into capital to be used by investors willing to capitalise it. Some areas seem to be particularly vulnerable to such evolution, of which one can enhance former industrial sites, whose industrial heritage is used as an element of authenticity to leverage gentrification processes. Furthermore, traditional centres of commerce and services are also particular prone to the match between the existence or production of authenticity, whether it may be objective or constructivist and its consumption, especially because these are the most visited areas by tourists. It is in this spatiality of authenticity, whether it may be real or just perceived or based on tangible or intangible assets that one's finds the link with retail gentrification. This is clearly evident in some town centres and high streets of Western countries. Despite they didn't stop being visited by tourists due to the elements of authenticity, several of them suffered from divestment and decline at some point in the last decades, thus increasing their rent gap. When positively affected by a surge of new visitors, these areas rapidly end up being valued, becoming attractive for retail capital from national and international chains. With that, the traditional commercial fabric is pressured to leave. A process of retail gentrification is, thus, completed with the appearance of a new commercial fabric that serves a new clientele and, to some extent, neglects former clients and calls into question the ability of some vulnerable population of their ability to supply.

Private investors, aware of the possibility of profiting with certain elements that are representative of the authenticity of a given area, use them for the reproduction of capital. By doing so, they pressure the old commercial fabric and may trigger retail gentrification. This process characterised by its ceaseless link with capital has two paradoxes. The first relates with the local users of these 'authentic' places. Even if not tourists, they possess with this former group a similar goal in the way they 'seek out authenticity as a counterforce to the alienation of everyday life' (Knudsen, Rickly, \& Vidon, 2016, p. 34). Ironically, by doing so and because of the wide-spread of places claiming for the authenticity that differentiates them from the mass-consumption stores, they eventually place themselves in a world-wide mass consumption trend. The second concerns with the gentrifiers stores. As Zukin (2011) attested, in deprived areas, especially the ones not subject to intense pressure from processes such as touristification, the initial role of independent entrepreneurs is crucial for enhancing those areas as consumption spaces, attracting new investors looking for business opportunities.

\section{Methodology}

In this article we will use a case study methodology at the intra-urban scale, conventionally adopted in retail geography studies (Johnston et al., 2000) aiming to uncover how authenticity is explored by retailers in Mouraria and discuss the links with retail 
gentrification processes. Fieldwork was developed in late 2018 in eleven streets that constitute a meaningful part of the core of this neighbourhood (Figure 1).

Although the option for a case study methodology influences the instruments that will be developed and implemented in the fieldwork, 'engaging with a case study approach is a decision about what is to be studied, not a methodological decision [...]' (Hesse-Biber, 2017 , p. 223). Primary data was collected. Interviews were done in person by the author to the business owners inside the respective establishment, in the end of 2018, using a note taking methodology. The interview sheet was composed of open-ended questions allowing the interviewee to expose their opinion 'about matters of actual significance to him rather than those presumed to be important by the interviewer' (Beuving \& Vries, 2015, p. 94). The set of questions and retail typologies of the stores in which the interview was conducted can be seen in Table 1. We interviewed not only the owners of newlyestablished stores but also the owners of the old ones that may be the next ones to be displaced. This option was done taking in consideration Slater, Curran, and Lees (2004), as this more comprehensive set of interviews could provide a clearer, more complex and accurate picture of the process under way, especially if we consider that one of the difficulties in gentrification studies is the ability to contact the ones that were

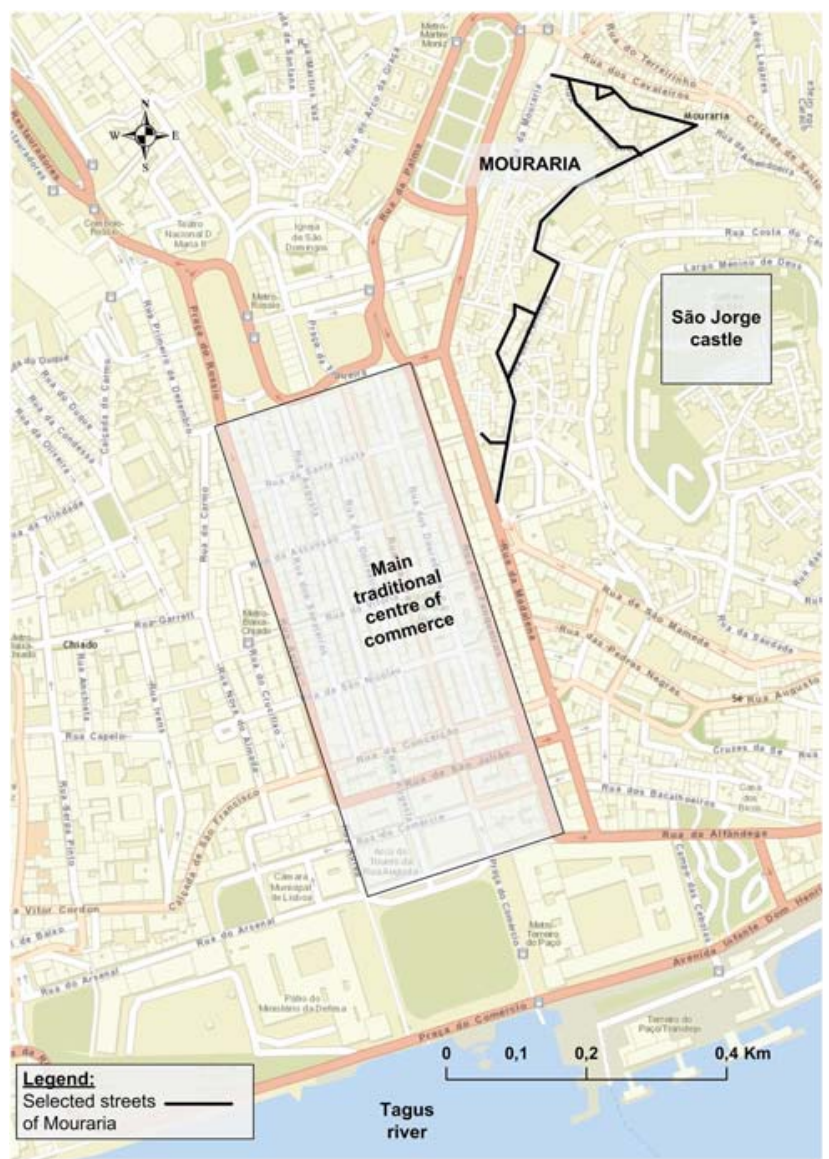

Figure 1. Location of Mouraria and selected streets for the fieldwork. Source: Author. 


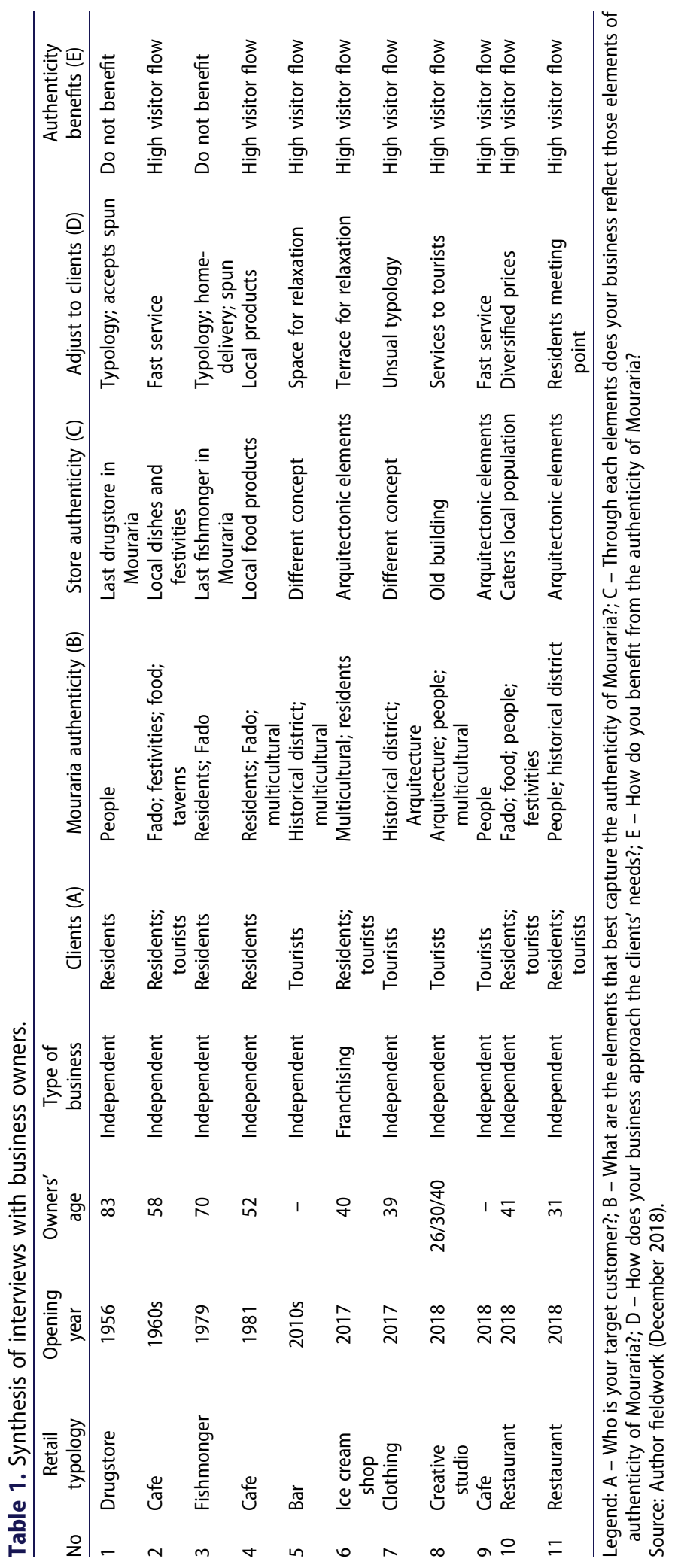


already impacted by such process and displaced (Slater et al., 2004). Prior to the fieldwork, we did not perform a selection of which business owners to interview. On the contrary, our goal was to interview as many as possible. Based on our previous personal experience, we were aware that a significant number of possible interviewees would not be willing to collaborate with our study for different reasons. This assumption revealed itself to be true and, overall, eleven in-depth interviews were performed, seven on retailers established in 2010s and four prior to the 1990s. During the fieldwork, data about the commercial fabric was collected and compared with data from the City Council from 1995 and 2007, allowing to trace the evolution of the area. The structure of the empirical section that follows, is similar to the one adopted by Zukin et al. (2009), dividing our section in different topics, which will help to enlighten about the analysed subject.

\section{Case study}

\section{Background}

The growth of tourism in Lisbon occurred in a stable pace in the last decades. However, in the final years of the 2000s, the growth of tourists was very intense as well as its effects. Internal issues, such as the liberalisation of national rental laws, the low price of real estate and the opening to low-cost aviation in combination with the global increase of tourism and the decline of traditional touristic places such as some destinations in North Africa, formed a crucial combination for such extreme development. In a process designed as touristification (Barata-Salgueiro et al., 2017), the acceleration of tourism, concentrated in a short period of time, triggered a series of impacts in a comprehensive array of sectors, of which housing and retail stand out (see Moreno-Gil and Coca-Stefaniak (2020) special issue). Due to the higher affluence of tourists to the central areas of cities, these are the places more vulnerable to the impacts of such process. In Lisbon it was no different and the traditional centre of commerce and historic old neighbourhoods in its vicinities form a continuous urban area that was first impacted by touristification.

Mouraria is an historic neighbourhood located in one of the slopes of São Jorge Castle. Its name is due to a former Muslim population that once was constrained within its boundaries. Mouraria is a traditional neighbourhood, in the sense it is somehow closed in itself and the social bounds among the population are very strong (Estevens, 2017). It is simultaneously characterised by being home of a high number of foreign population. Additionally, the imaginary of the neighbourhood is intrinsically linked to Fado, a Portuguese musical genre. It is through this panoply of elements, not always homogeneous that Mouraria shows its authenticity.

\section{Changing retail scene}

Although it is not the focus of this research, we must bear in mind that the evolution that we are going to further analyse must be understood within a broader process of transformation of the city. Firstly, the urban expansion of the city and region occurred simultaneously with the decline of the city centre, most likely enhancing the depth of the decline of this area. Secondly, recent rehabilitation policies, triggered and encouraged by public authorities incited a significant transformation of the city centre, with tourism 
leading the process (Tulumello, 2016). As Barata-Salgueiro and Guimarães (2020) analyse, aiming to counteract the district decline, the evolution of retail in Lisbon city centre in the new millennium is strongly influenced by a diverse set of strategic and master plans. In this understanding, retail has been simultaneously influenced by these urban policies, but also a vehicle that is consolidating the transition of Lisbon city centre into a leisure and consumption area.

The evolution of the tenant mix of Mouraria mirrors the traditional evolution of central city districts. It reflects the transition of a central area where the residential function has once been more relevant.

Food retail is clearly one of the retail typologies illustrative of this evolution (Figure 2). In 1995, this typology still represented almost a third of the total number of existing businesses in Mouraria. In late 2018 only four groceries remain. Of these, only one is representative of the old retailers, a fishmonger opened in 1979. The remaining three are small establishments owned by South Asian individuals, from Bangladesh, Pakistan and also Nepal, as a part of a set of investments in this kind of stores throughout the city (Malheiros, Estevens, Carreiras, Guimarães, \& Fonseca, 2016). Despite relevant to counteract the decline of the number of groceries in central districts, these businesses are more similar to convenience stores than to traditional dairy shopping stores, which means they do not meet the needs that arise with the lack of groceries or supermarkets. Contrarily to what one should expect, the typology 'household and personal goods' is under-represented in the area in the three different years. Encompassing businesses such as clothing, the geographical location of Mouraria help to shed some light on the small representation of this typology. The close proximity to Baixa (see Figure 1), where some of most important high streets of Lisbon are located, discourages the opening of this type of stores in Mouraria. The rise of establishments from this retail typology in 2018 is due
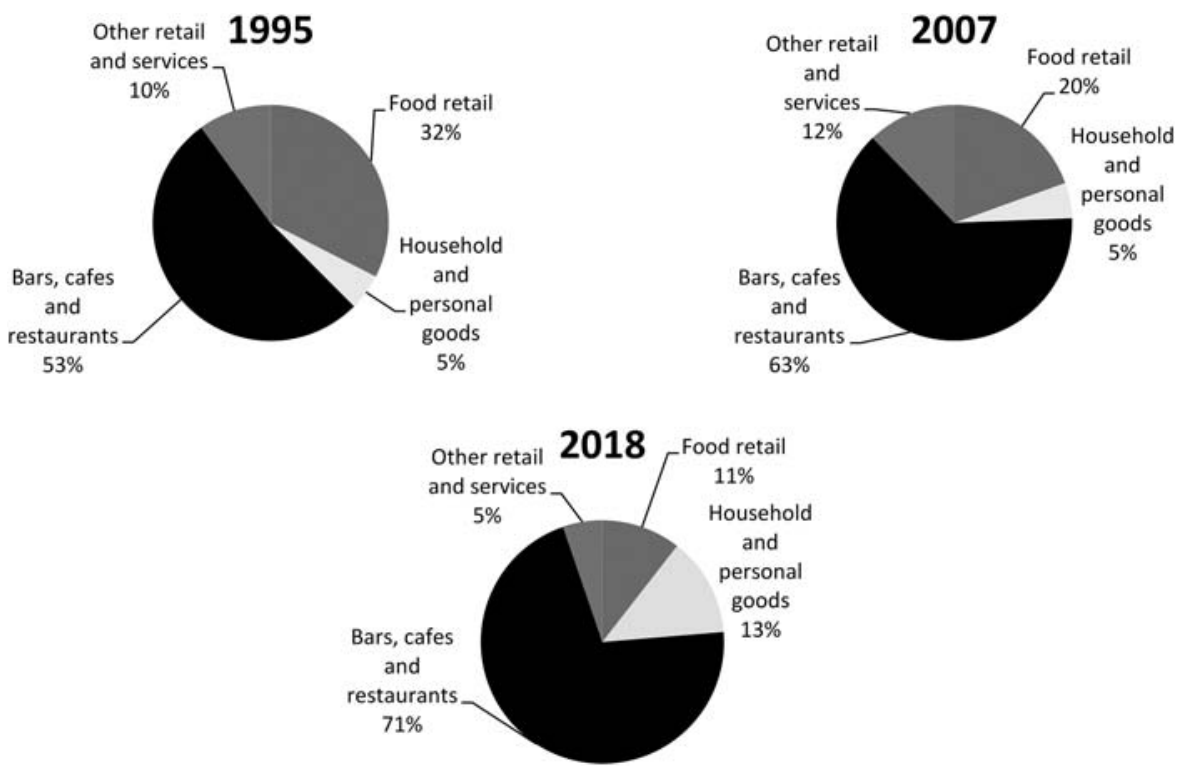

Figure 2. Mouraria tenant mix in 1995, 2007 and 2018. Source: CML (1995, 2007); author fieldwork (2018). 
to the growing influence of tourism because most of new stores cater tourists, being the two hand-made ceramic shops a clear example of this evolution. Nevertheless, as expected, the typology that best illustrates the rising importance of tourism is the one that encompasses bars, cafes and restaurants. In 2018, almost 3/4 of all establishments are from this typology. The new composition of the commercial fabric reflects the growing importance of the area for leisure and consumption, whose evolution finds some similarities with some existent studies, such as Gotham (2005) analysis of New Orleans, that unveiled the connection between a similar evolution of the commercial fabric with a broader process of tourism gentrification.

This ongoing transformation did not produce changes in terms of the entrepreneurial characterisation of the commercial fabric. Corporate retail is not expressive in the neighbourhood. Almost all stores are independent, several of them represent investments of local long-term residents that, reacting to the rising number of tourists, opened new stores to cater this new affluent clientele. Because a high number of stores have been disappearing from the area (Table 2) it means their substitution is being done by other independent stores. As aforementioned, Zukin (2011) confirmed the importance of this noncorporate businesses in triggering urban transformation associated with retail gentrification; thus the current evolution of Mouraria seems to place the area within an early stage of such a process. The rotation and substitution of stores is a clear indication of current changes in the area. Although the substitution of stores is a normal occurrence within the geographies of retailing, the different rhythms at which they transpired can provide useful insights. As we can see in Table 2, the size of the commercial fabric has remained similar in the three years under analysis.

Alongside the change in the composition of the tenant mix, one can see that the process of change intensified in the years following 2007, coinciding with the intense rise of tourism industry and touristification impacts. From 1995 to 2007, sixteen stores disappeared, corresponding to a rotation rate of $40 \%$. In the following period, thirty stores vanished from the area, resulting in a rotation rate of $73 \%$. Furthermore, the overall rotation rate from 1995 to 2018 is $77.5 \%$, which means that the main transformation took place after 2007, following the increase of tourism. Thus, the characteristic of the current commercial activity that exists in Mouraria reflects the touristification of Lisbon city centre.

\section{Elements of authenticity in Mouraria}

In our empirical analysis we performed eleven in-depth interviews on business owners of Mouraria (see Table 1), whose questions are in accordance with the research questions established in the introduction section. Regarding the question 'what are the elements

Table 2. Retail evolution in selected streets

\begin{tabular}{lc}
\hline Total of units in 1995 & 40 \\
Total of units in 2007 & 41 \\
Total of units in 2018 & 38 \\
Disappeared from 1995 to 2007 & $16(40 \%)$ \\
Disappeared from 2007 to 2018 & $30(73 \%)$ \\
Disappeared from 1995 to 2018 & $31(77.5 \%)$ \\
\hline
\end{tabular}

Source: (CML, 1995, 2007); author fieldwork (December 2018). 
that best capture the authenticity of Mouraria?', their response was not so immediate, which cannot be detached from the fact that some of the retailers are themselves residents in the neighbourhood. This is in line with the way authenticity connects with a 'space of representation', i.e. as Zukin (2008) discusses, the elements that an outsider finds authentic may not be perceived as such by a long-term resident, who just face those same elements as a part of their daily life. Whereas some studies show us (see for instance Martínez, 2016; Thomsen, 2018; Trihn, Ryan, \& Cave, 2014) that authenticity can assume different forms, reflecting the specificities that better defines each area, in Mouraria no single element seems to really capture the neighbourhood.

We have assembled the collected responses in three groups that encompasses the different elements considered by the interviewees as representative of the neighbourhood: (i) Community values; (ii) Multiculturality; (iii) Urban features. Community values is the element that gathers more consensus. Nine in eleven interviewees mentioned it. It is connected with the strong sense of community and social bounds established among long-term residents. Embedded within these community values is Fado, a traditional Portuguese music genre that was included in 2011 in the UNESCO'S list of World's Intangible Cultural Heritage. It is said that Mouraria was the cradle of Fado. When searching for authenticity in Lisbon, hardly one may find a more emblematic symbol than Fado, a Portuguese musical genre. In addition to being a cultural expression of the city, in general, in Mouraria it has a dimension with scarce correspondence in most of the other districts of the city. Thus, although it is mainly an intangible heritage, it produces and reproduces physical manifestations in territory, such as the specific Fado Houses or the several restaurants and taverns located in the more traditional Lisbon neighbourhoods. Moreover, this cultural expression is also represented in the walls of Mouraria, as one can see in Figure 3, a mural painted in homage to Fado, thus connecting with the belowdiscussed element (urban features).

Multiculturality connects with the heterogeneous background of residents in Mouraria. Evoking a past marked by the strong presence of Muslim population in this neighbourhood, at present, the number of residents coming from different countries is still a landmark that distinguishes the neighbourhood. These answers corroborates Carmo and Estevens (2017), who have argued that, currently, the interethnic composition of the Mouraria, together with some folk imagery, such aforementioned Fado, are essential in the construction of the image and identity of the neighbourhood. In their research, these authors also enhanced the role of public initiatives, that resorting to those elements as vehicles of urban transformation, aimed to reshape the Mouraria image. Urban features is the element emphasised by interviewees whose interpretation is not so straightforward. Because it refers to physically-defined aspects, it can be apprehended in twofold: (1) in the retail places that compose the commercial fabric of Mouraria, because they possess elements representative of the past memories of the neighbourhood; (2) in the buildings and streets of Mouraria, insofar as both, although not exclusively seen in this neighbourhood, are truly representative of old Lisbon. The irregular urban grid of Mouraria that contrasts with the regular urban grid of Baixa just located in its vicinities and the sloping narrow streets which are filled by several small stairways attracts a wide number of tourists, especially because it is also the path that leads to the entrance of the castle of São Jorge (a major tourist hotspot) (Figure 4). 


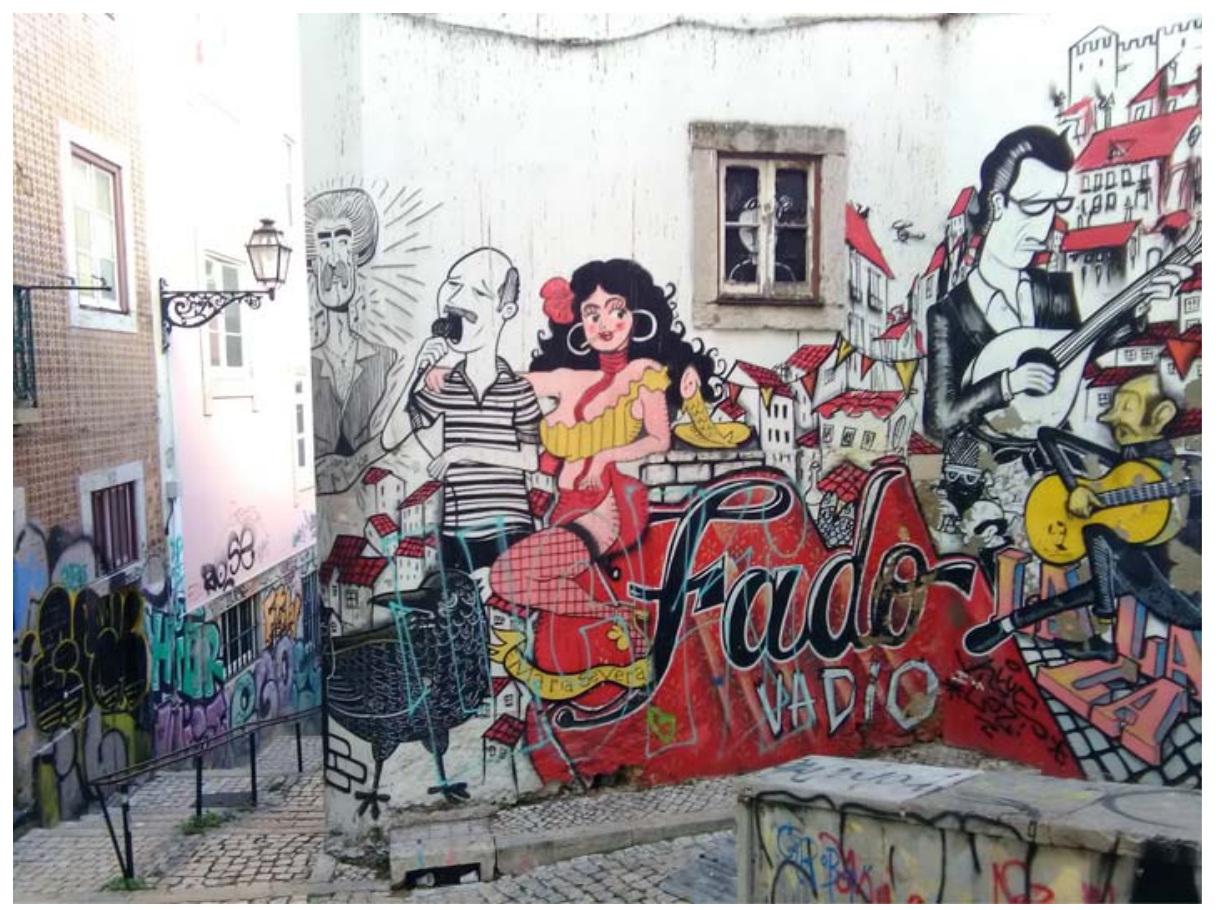

Figure 3. Mural in tribute to Fado. Source: Author.

\section{Use of Mouraria elements of authenticity by retail stores}

The way by which stores appropriate and use the authenticity of Mouraria is diverse and not always a perfect match with the above-mentioned three groups of elements. Aware that they are located in an historic neighbourhood, most business owners chose to consider authenticity in different ways that we can fit within the objective and constructivist authenticity perspectives, quite often not detached from one another. According to what interviewees told us, a significant number of stores possess elements that fit objective authenticity. The stores numbered as 2 and 4 in Table 1, both cafes, still offer the same menu since their opening in the 1960s and 1981, respectively. Their offer is genuine in the sense it remained unchanged and is made of traditional food and beverages (such as Ginjinha, a Lisbon traditional alcoholic drink) and still caters local residents. The store numbered as 10 was inaugurated in 2018 and is owned by a long-term resident in Mouraria and also fits within this retail typology and applies a positive discriminatory measure a cheaper price for residents and a more expensive price for tourists, thus, not excluding local resident from the possibility of accessing local establishments.

I was born and still live in Mouraria. I believe that tourists should pay a little more because they can afford more than some of the local inhabitants. (restaurant business owner, personal communication. Author translation)

Another two stores are meaningful to this investigation because they are the last two stores of the respective retail typology, namely a fishmonger and a drugstore. They connect with the authenticity of Mouraria as representatives of a commercial fabric that no longer exists. 


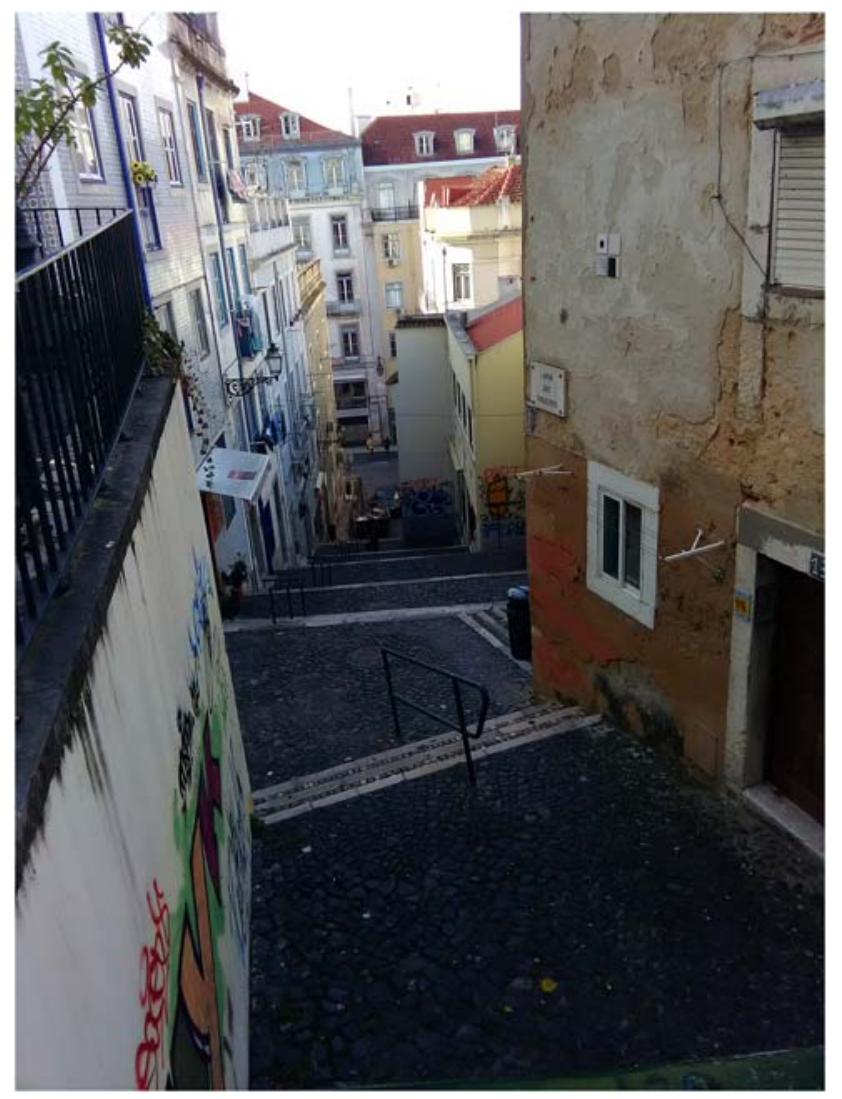

Figure 4. Slopping streets in Mouraria. Source: Author.

These stores are the ones, in Mouraria, that better fit the objective authenticity, as the physical appearance of the store, as well as the traded products remain, to some extent, scarcely unaltered since their inauguration (1956 and 1979). Moreover, they still execute commercial practices that have since fallen into disuse or changed significantly. The epitome of such practices is a line of credit given to long-term residents. Such credit is made only on the basis of personal knowledge between the seller and the buyer and does not involve third parties as credit providers. As it was mentioned by the interviewee:

I allow for the debt payment to be made later in the month when the client receives money from the salary or from the retirement fund because otherwise some of them could not buy fish. Furthermore, because some older clients have mobility issues, I also practice home-delivery to clients that request it without further payment. (fishmonger business owner, personal communication. Author translation)

The existence of such practices should also be seen as the confirmation that in Mouraria some residents depend on these type of retail spaces to be able to supply themselves. In this case, the deepening of retail gentrification as a result of continuous pressure from the tourism industry, will be detrimental not only for the traditional retail spaces but also for the most disadvantaged local residents. Moreover, the aforementioned described examples of how authenticity is represented in the stores of Mouraria possess not only 
an objective authenticity but also a psychosocial dimension (see Park, Choi, \& Lee, 2019), in the sense that those elements are embedded with certain values and behaviours. This is attested by an element clearly identifiable in the neighbourhood that was not orally mentioned by interviewees. We are referring to the name of the establishments; for instance, the term Tasca and Taberna refers to old taverns, whose clients were working-class local residents, which contradicts with present costumers, mainly tourists. In a similar way, one store also uses the term Fado, which further deepens the connection with the neighbourhood. The use of these terms connects with the space of representation (Zukin, 2008), as previously discussed. It represents an approach to project authenticity to retail spaces. This projection is essentially for outsiders, as traditional old stores do not need to explicitly advertise these elements, as they are 'naturally' understood by locals, without the need to be reminded. Paradoxically, the evolution of the area, the combined and intrinsic link between retail change and gentrification in Mouraria may result in the appearance of several new retail spaces that use this kind of elements of authenticity that are no more than pastiche of a non-existent commercial fabric.

In a different way, a more tangible dimension of authenticity can also be seen in other stores, of which one must enhance the physical features of the stores and the buildings. In this sense, architectural features are seen as a valuable asset, such as the original foundations of the buildings, as corroborated by one of the interviewees

I've restored and continuously preserve the original wall of the building. It is something that I cherish as it is connected with the memory of the place. (ice cream shop business owner, personal communication. Author translation)

This example shows how a retail space can appropriate a specific element of authenticity, even if the business in itself (store $n^{\circ} 6$ in Table 1 ) is totally detached from being considered as an authentic retail place from the neighbourhood. Objective authenticity can also be seen in some façade elements as well as in the furniture of some stores that was intentionally maintained as remnants of previous retail typologies. As the business owner of a store opened recently (2018) said

my business is authentic as I use some of the same furniture of the previous business (bakery, now a coffee shop), as well as the same iron doors and decorative architectural elements.

(coffee shop business owner, personal communication. Author translation)

In this latter example, the former retail typology was replaced by a new one; in the place of a former bakery, a modern coffee shop was inaugurated. This means that this objective authenticity is produced just by the existence of 'genuine' (see Cohen, 2007) elements. This understanding is in line with object-based authenticity approach (Kolar \& Zabkar, 2010). Real objects are seen as representative of a certain authenticity and maintained and cherished as if they are displayed in a museum. As described by Reising and Steiner (2006) by resorting to Cohen (1988, p. 71), during 'the process of commoditization [...] (mass) tourism may guarantee the maintenance of certain original traditions, designs, values, or craft skills'. In Mouraria, that set of urban features assume those functions. Less relevant is the number of interviewees that state that the authenticity of their stores is not connected with Mouraria but because these same stores introduced new features to the already existent commercial fabric of the area. As one interviewee referred 
Mouraria didn't have this kind of the bar and as we are on the direct route to the castle we have a lot of tourists passing-by and several eventually stop. (bar business owner, personal communication. Author translation)

The three stores that are included in this understanding of authenticity were inaugurated already during the period of expansion of tourism in Lisbon, cater tourists as their target costumer and include a creative studio, a bar and a second-hand vintage clothing store. Detached from the neighbourhood history in the sense they do not use any elements that invokes Mouraria, they provide a new case of authenticity seen as 'genuineness', as analysed by Cohen (2007). Unlike the other retail spaces, whose authenticity derives from the connection with traditional elements of the neighbourhood, the authenticity of these three stores, according to their owners, derives precisely because they are different; which is similar to one of Zukin (2009) understanding of authentic stores, i.e. to be seen as retail stores that that differ from existing commercial fabric.

\section{Discussion and conclusion}

In this article we aimed to study the relation between authenticity and retail within a framework of retail gentrification, a process that currently characterises the evolution of retail in a growing number of urban districts. We further aimed to analyse how business owners of a given area explore the authenticity of the respective area. Using a case study methodology, the traditional neighbourhood of Mouraria in Lisbon was the territorial space where fieldwork was developed. Resuming our initial research questions 'Which elements are considered as most representative, distinguishing and authentic of Mouraria?' and 'Are retail stores of Mouraria using these elements, and if so, how?' it became clear that authenticity is consciously used by retailers in their businesses and the diversity of ways in which elements considered as authentic are incorporated into stores is significant. Besides the theoretical considerations that one provides about the concept, in retail, authenticity, thus, arise as a management practice. From the production perspective that we've adopt in this research, the deliberated use of authenticity elements, especially in the retail spaces more recently inaugurated, fit, most of all, the objective and constructivist approach. As uncovered in the interviews, the former approach is clearly seen in the maintenance of the physical structure of buildings, such as the original wall that was maintained while the rest of the establishment has a modern decoration architecture; in the use of old furniture as reminiscences of previous uses and retail typologies; or in the conservation of the stores façade of the establishments. Nevertheless, viewing these features as merely originals is incomplete and, therefore, constructivist approach is also helpful to understand how these elements considered to possess authenticity are valued by retailers. In fact, the value of these elements relay on the fact that they are fragments of a neighbourhood that has changed and evolved. The mural (Figure 3) painted in the walls of the neighbourhood is part of the production of the constructivist authenticity of Mouraria. Nevertheless, there are some exceptions; mainly through the use of authenticity in retail spaces from the prism of differentiation, i.e. as analysed in the end of the latter section, the authenticity of these retail spaces is based on its distinction from other establishments from Mouraria and not on a possible deeper connection with this neighbourhood. To some extent, a different reading can be done regarding stores that exist in the location for longer. These stores do not use the authenticity of Mouraria as 
an intentional strategy, mainly because these same stores, due their antiquity and specificity of the retail typology, are by themselves part of the authentic elements of Mouraria. The authenticity of those stores relays on what Cohen (2007) called as genuineness, in the way that what they offer is unadulterated. Somehow, their antiquity in what concerns the physical appearance of the store, the traded products and commercial practices is what legitimize their authenticity.

The geographical location of Mouraria, in close distance to the high streets of the city centre and also on the path to the entrance of São Jorge castle, provide this area with a substantial affluence of tourists, justifying and enabling some entrepreneurs to open businesses in the area. As discussed by Cohen (2007), tourists stand in the paradox that is their search for unique experiences and the reality of tourism industry that provide a homogenisation of tourism destinations and amenities. In this way, objective and constructivist authenticity offered by retail spaces in Mouraria arises as a way to comply with the tourists search for existential authenticity. This connection can be found in the specific terms used in the name of the establishment, such as 'tasca' or 'fado', both connected with the traditional roots of Mouraria. Overall, in Mouraria this process of retail change and adaptation to cater tourists can't be read as being black or white. Objective and constructivist authenticity co-exist in Mouraria in different ways. The appropriation of authenticity in retail stores is mainly understood as such by outsiders, thatlegitimize (and make viable) the presence of these establishments. Thus, because retail is a private activity and aims to obtain profit, authenticity is an asset for the capitalisation of private investments and their viability is dependent on the tourists that visit Mouraria. Thus, there is a symbiotic relation between retail that offer objective and constructivist authenticity and tourists that search for existential authenticity.

Regarding the question 'What are the territorially visible impacts that arise from this process?', the most significant change is the loss of diversity in the tenant mix. Due to the continuous growth of the typology of bars, cafes and restaurants, strongly connected with touristic areas, the commercial landscape of Mouraria is becoming homogeneous. However, one may enhance that these changes are exacerbated because they accompany other structural changes. Thus, one should see this change not only as a direct consequence of the growth of tourism but also as a consequence of a series of transformations in Lisbon, such as the loss of population living in the city centre. As already confirmed in the literature (see Bromley and Thomas (1993) and Guimarães (2016)) this change can be framed within an evolutionary path that characterises a large number of Western European cities. Nevertheless, current situation is pushing changes to go further in what concerns the scale of the transformations and the speed at which they occur. We've found similarities in the evolution of the tenant mix of Mouraria with the evolution described in well-known studies such as Gotham (2005) and Zukin (2008), which place Mouraria commercial fabric within an early stage of retail gentrification. Mouraria presents itself as an example of these kind of processes. In the present stage, the transformation is being led by local and/or independent entrepreneurs and anchored on tourism. As Zukin (2011) unfolded, the role of the initial entrepreneurs is crucial in the transformation of a given area into consumption spaces, which does not mean that impacts are not produced. Calling upon another research of this author: 'entrepreneurs who cater to the new residents create consumption spaces that, to old residents, are just as unwelcoming' (Zukin, 2008, p. 731) - which stress the tensions between old and new businesses and 
residents. As new and old stores may provide authentic experiences to the one that visits Mouraria, they can contribute to the artificial museumfication of the area. Consequently, by targeting a specific clientele, it may exclude and increase the vulnerability in the access to consumption by other groups; thus, the current commercial fabric of Mouraria (and its evolution) is detrimental for the population that still live in this neighbourhood as it is mostly oriented towards tourists.

In conclusion, objective, constructivist and existential authenticity co-exist and interact in different ways in Mouraria. Together they endow Mouraria of spatial capital, unique to the extent that the amount in which each of the elements can be found in this area is specific to this area. This uniqueness is reinforced by the way through which the particular elements of the neighbourhood that constitute its authenticity reinforce each other. For instance, objective authenticity represented in the urban elements, increase their value because they are connected with the memory of the neighbourhood, valued by tourists that, as said by Park et al. (2019, p. 100), 'get motivated by the desire to experience somebody else's culture'. Also important to note how the opposite process also seems to occur. Some intangible authenticity elements representative of the 'strong sense of community' apparently are reinforced by this production of authenticity in Mouraria, that finds in retail a physical mechanism to their perpetuation, such as Fado, an intangible heritage that is perpetuated in Fado houses, some of which owe their viability to tourists searching for authentic experiences. Thus, is not only the existence of a certain set of authentic elements that constitute the authenticity of Mouraria but the way they co-exist, reinforce each other, producing manifestations and impacts in this confined neighbourhood.

This article intended to present some discussion and insights about the relation between authenticity and retail gentrification. We recognise that both concepts and the processes they imply in urban spaces possess many variances. Our choice to analyse authenticity from the three perspectives does not imply that we do not recognise that there are others (for instance Bruner, 1994; Zukin, 2008), which we do not consider to be better or worse, but just different. Beside the theoretical discussion, we have privileged the production perspective. For future research, it would be interesting to further investigate the consumption perspective of the same process.

\section{Disclosure statement}

No potential conflict of interest was reported by the author(s).

\section{Notes on contributor}

Pedro Guimarães has a PhD in Geography. His research interests revolve around urban geography, with a particular focus on the analysis of urban transformations and on the relation between cities and retail. Within this research field, he has published in international journals, among others, on the subjects of retail gentrification; public policies; resilience; demalling; and urban regeneration.

\section{Funding}

This work was supported by Fundação para a Ciência e a Tecnologia Project 'PHOENIX - Retail-Led Urban Regeneration and the New Forms of Governance' - PTDC/GES -URB/31878/2017). 


\section{ORCID}

Pedro Porfírio Coutinho Guimarães (1) http://orcid.org/0000-0001-9011-8894

\section{References}

Aalbers, M. (2019). Revisiting 'The changing state of gentrification' - Introduction to the forum: From third to fifth-wave gentrification. Tijdschrift voor economische en sociale geografie, 110(1), 1-11.

Barata-Salgueiro, T., \& Guimarães, P. (2020). Public policy for sustainability and retail resilience in Lisbon City Center. Sustainability, 12, 9433.

Barata-Salgueiro, T., Mendes, L., \& Guimarães, P. (2017). Tourism and urban changes. Lessons from Lisbon. In M. Gravari-Barbas, \& S. Guinand (Eds.), Tourism and gentrification in contemporary metropolises (pp. 255-275). London: Routledge.

Beuving, J., \& Vries, G. (2015). Doing qualitative research, the craft of naturalistic inquiry. Amsterdam: Amsterdam University Press.

Bounds, M., \& Morris, A. (2006). Second wave gentrification in inner-city Sydney. Cities, 23(2), 99-108.

Bromley, R., \& Thomas, C. (1993). Retail change - Contemporary changes. London: UCL Press.

Brown, L. (2013). Tourism: A catalyst for existential authenticity. Annals of Tourism Research, 40, 176190.

Bruner, E. (1994). Abraham Lincoln as authentic reproduction: A critique of postmodernism. American Anthropologist, 96(2), 397-415.

Cachinho, H., \& Barata-Salgueiro, T. (2016). Os sistemas comerciais urbanos em tempos de turbulência: vulnerabilidades e níveis de resiliência. Finisterra, 101, 89-109.

Carmo, A., \& Estevens, A. (2017). Urban citizenship(s) in Lisbon: Examining the case of Mouraria. Citizenship Studies, 21(4), 409-424.

Castéran, H., \& Roederer, C. (2013). Does authenticity really affect behavior? The Case of the Strasbourg Christmas Market. Tourism Management, 36, 153-163.

CML. (1995). Levantamento functional do comércio e serviços 1995. Lisboa: Câmara Municipal de Lisboa.

CML. (2007). Levantamento functional do comércio e serviços 2007. Lisboa: Câmara Municipal de Lisboa.

Cohen, E. (1988). Authenticity and commoditization in tourism. Annals of Tourism Research, 15, 371-386.

Cohen, E. (2007). 'Authenticity' in tourism studies: Aprés la Lutte. Tourism Recreation Research, 32(2), $75-82$.

Crewe, L. (2000). Geographies of retailing and consumption. Progress in Human Geography, 24(2), 275-290.

Estevens, A. (2017). A cidade neoliberal: conflito e arte em Lisboa e em Barcelona. Porto: Deriva.

Fan, J., Tang, L., Zhu, W., \& Zou, B. (2018). The Alibaba effect: Spatial consumption inequality and the welfare gains from e-commerce. Journal of International Economics, 114, 203-220.

$\mathrm{Fu}, \mathrm{X}$. (2019). Existential authenticity and destination loyalty: Evidence from heritage tourists. Journal of Destination Marketing \& Management, 12, 84-94.

Gelmers, W. (2015). Specialty coffee bars: Are they to stay or to go?. Retrieved from http://theprotocity. com/specialty-coffee-bars/

González-Pérez, J. (2018). Urban Inequality: The city after the 2007 crisis. Urban Science, 2(3), 1-5.

Gotham, K. (2005). Tourism gentrification: The case of New Orleans Vieux Carré (French Quarter). Urban Studies, 42(7), 1099-1121.

Grimsey, B. (2018). The Grimsey review 2. Retrieved from http://www.vanishinghighstreet.com/wpcontent/uploads/2018/07/GrimseyReview2.pdf

Guimarães, P. (2016). Revisiting retail planning policies in countries of restraint of Western Europe. International Journal of Urban Sciences, 20(3), 361-380.

Guimarães, P. (2018a). The transformation of retail markets in Lisbon: An analysis through the Lens of retail gentrification. European Planning Studies, 26(7), 1450-1470.

Guimarães, P. (2018b). The resilience of shopping centres: An analysis of retail resilience strategies in Lisbon, Portugal. Moravian Geographical Reports, 26(3), 160-172. 
Guimarães, P. (2019). Shopping centres in decline: Analysis of demalling in Lisbon. Cities, 87, 21-29. Hackworth, J. (2019). Gentrification as a politico-economic window: Reflections on the changing state of gentrification. Tijdschrift voor economische en sociale geografie, 110(1), 47-53.

Harvey, D. (2012). Rebel cities, from the right to the city to the urban revolution. London: Verso.

Hesse-Biber, S. (2017). The practice of qualitative research. Thousand Oaks: SAGE Publications.

Hubbard, P. (2018). Retail gentrification. In L. Lees, \& M. Philips (Eds.), Handbook of gentrification studies (pp. 294-309). Croydon: Edward Elgar Publishing.

Hubbard, P., \& Lees, L. (2018). The right to community? City, 22(1), 8-25.

Johnston, R., Gregory, D., Pratt, G., \& Watts, M. (2000). ). The dictionary of human geography (4th ed.). Cornwall: Blackwell Publishing.

Knudsen, D., Rickly, J., \& Vidon, E. (2016). The fantasy of authenticity: Touring with Lacan. Annals of Tourism Research, 58, 33-45.

Kolar, T., \& Zabkar, V. (2010). A consumer-based model of authenticity: An oxymoron or the foundation of cultural heritage marketing? Tourism Management, 31, 652-654.

Lees, L. (2018). Introduction: Towards a C21st global gentrification studies. In L. Lees, \& M. Phillips (Eds.), Handbook of gentrification studies (pp. 1-10). Cheltenham: Edward Elgar Publishing, Inc.

Lees, L., Slater, T., \& Wyly, E. (2008). Gentrification. New York: Routledge.

Lévy, J. (1994). L'espace légitime. Sur la dimension géographique de la fonction politique [The legal space. About the geographical dimension of political function]. Paris: Les Presses de Sciences Po.

Malheiros, J., Estevens, A., Carreiras, M., Guimarães, P., \& Fonseca, L. (2016). Diversity in the economy and local integration (DELI) Lisbon. Retrieved from:https://rm.coe.int/16806667a9

Martínez, P. (2016). Authenticity as a challenge in the transformation of Beijing's urban heritage: The commercial gentrification of the Guozijian historic area. Cities, 59, 48-56.

Mayhew, S. (2015). Oxford dictionary of geography (5th ed.). Oxford: Oxford University Press.

Moreno-Gil, S., \& Coca-Stefaniak, A. (2020). Overtourism and the sharing economy - tourism cities at a crossroads. International Journal of Tourism Cities, 6(1), 1-7.

Park, E., Choi, B., \& Lee, T. (2019). The role and dimensions of authenticity in heritage tourism. Tourism Management, 74, 99-109.

Portas, M. (2011). Portas report. Retrieved from https://assets.publishing.service.gov.uk/ government/uploads/system/uploads/attachment_data/file/6292/2081646.pdf

Reising, Y., \& Steiner, C. (2006). Reconceptualizing object authenticity. Annals of Tourism Research, 33 (1), 65-86.

Scottish Government. (2013). National review of town centres external advisory group report: Community and enterprise in Scotland's town centres. Edinburgh: Scottish Government.

Shaker, R., \& Rath, J. (2018). The coffee scene in Glasgow's West End: On the class practices of the new urban middle classes. City, Culture and Society, 17, 1-7.

Sims, R. (2009). Food, place and authenticity: Local food and the sustainable tourism experience. Journal of Sustainable Tourism, 17(3), 321-336.

Slater, T. (2006). The eviction of critical perspectives from gentrification research. International Journal of Urban and Regional Research, 30(4), 737-757.

Slater, T., Curran, W., \& Lees, L. (2004). Gentrification research: New directions and critical scholarship. Guest editorial. Environment and Planning A, 36(7), 1141-1150.

Smith, N. (2002). New globalism, new urbanism: Gentrification as global urban strategy. Antipode, 34 (3), 427-450.

Smith, N. (2006). Gentrification generalized: From local anomaly to urban 'regeneration' as global urban strategy. In M. Fisher, \& G. Downey (Eds.), Frontiers of capital: Ethnographic reflections on the new economy (pp. 191-208). Durham: Duke University Press Books.

Thomsen, L. (2018). Retailing in places of world heritage, transition and 'planned authenticity'. Geoforum; Journal of Physical, Human, and Regional Geosciences, 91, 245-252.

Trihn, T., Ryan, C., \& Cave, J. (2014). Souvenir sellers and perceptions of authenticity e The retailers of Hội. Tourism Management, 45, 275-283.

Tulumello, S. (2016). Reconsidering neoliberal urban planning in times of crisis: Urban regeneration policy in a 'dense' space in Lisbon. Urban Geography, 37(1), 117-140.

Wacquant, L. (2004). Critical thought as solvent of doxa. Constellations (Oxford, England), 11(1), 97-101. 
Wang, N. (1999). Rethinking authenticity in tourism experience. Annals of Tourism Research, 26(2), 349-370. Wrigley, N., \& Lowe, M. (eds.). (1996). Retailing, consumption and capital: Towards the new retail geography. Harlow: Addison Wesley Longman.

Wrigley, N., \& Lowe, M. (2002). Reading retail - A geographical perspective on retailing and consumption spaces. London: Arnold.

Zhu, Y. (2015). Cultural effects of authenticity: Contested heritage practices in China. International Journal of Heritage Studies, 21(6), 594-608.

Zukin, S. (2008). Consuming authenticity. Cultural Studies, 22(5), 724-748.

Zukin, S. (2009). Changing landscapes of power: Opulence and the urge for authenticity. International Journal of Urban and Regional Research, 33(2), 543-553.

Zukin, S. (2011). Reconstructing the authenticity of place. Theory and Society, 40(2), 161-165.

Zukin, S., Trujillo, V., Frase, P., Jackson, D., Recuber, T., \& Walker, A. (2009). New retail capital and neighborhood change: Boutiques and gentrification in New York city. City and Community, 8 (1), 47-64. 